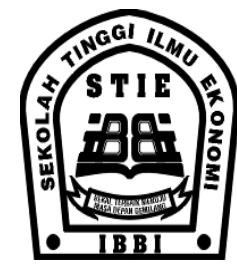

ISSN 1858-3202

JURNAL

BINA AKUNTANSI

IBBI

\title{
AUDIT DELAY PADA PERUSAHAAN LQ 45 YANG TERDAFTAR DI BEI
}

\author{
Boy Fadly, S.E.,M.Ak. ${ }^{1)}$, Melia Novita,S.Ak. ${ }^{2)}$ \\ ${ }^{1}$ STIE IBBI \\ ${ }^{2}$ STIE IBBI
}

\begin{abstract}
Abstrak/ Abstract
One of the qualitative characteristic attribute of financial statement reporting is relevant, that is manifestation can be seen from the timeliness of reporting. Timeliness could be judging from the audit delay, which is the time required auditors to complete the audit process, calculated from a company fiscal year end to the date of auditor's report. The purpose of this study was to analyze the influence of firm size, the age of company, complexity of company's operations, reputation of public accounting firm, and auditor's opinion towards audit delay of LQ 45 companies registered in The Indonesia Stock Exchange.

The population of this study was all of LQ 45 companies registered in the Indonesia Stock Exchange. 31 samples of the population obtained through purposive sampling method. This study uses secondary data, which is financial statements of $L Q 45$ companies registered in The Indonesia Stock Exchange.Multiple linear regression tests is used to prove the hypothesis. Otherwise regression model has passed the classic assumptions test.

The results showed the significance of each of the variables: the size of the company $(0,000)$, a company's age (0.471), the complexity of the company's operations $(0,008)$, the reputation of KAP (0,012), and audit opinion (0.112). Adjusted R Square obtained amounted to 0.376, which means that $37.6 \%$ of audit delay is influenced by firm size, firm age, the complexity of the company's operations, reputation KAP and audit opinion.

The conclusions of the research result, simultaneous shows that independent variables affect the dependent variable and the partial test results show that there are 3 of 5 factors that affect audit delay, they arefirm size, complexity of company's operations, and reputation of public accounting firm. While 2 factors that has no effect are the age of company, and auditor's opinion.
\end{abstract}

Keywords: Firm size, the age of company, complexity of company's operations, reputation of public accounting firm, auditor's opinion, and audit delay.

\section{PENDAHULUAN}

Perusahaan go public di Indonesia ditutntut untuk dapat melaporkan keuangannya tepat waktu dan diperiksa oleh auditor pada waktu yang telah ditentukan. Seperti peraturan yang dikeluarkan oleh Keputusan Ketua BAPEPAM-LK No.Kep-134/BL/2006 Tentang Kewajiban Penyampaian Laporan Tahunan Bagi Emiten dan Perusahaan Publik serta Keputusan Ketua BAPEPAM-LK No.Kep-40/BL/2007 Tentang Jangka Waktu Penyampaian Laporan Keuangan Berkala dan Laporan Tahunan Bagi Emiten atau Perusahaan Publik yang Efeknya Tercatat di
Bursa Efek di Indonesia dan di Bursa Efek Negara Lain, yang kemudian kedua peraturan tersebut dicabut dan diganti dengan Keputusan Ketua BAPEPAM No. Kep-431/BL/2012, No.1 Peraturan X.K.6 Tentang Penyampaian Laporan Emiten atau Perusahaan Publik,yang menyatakan bahwa Emiten atau Perusahaan Publik yang pernyataan pendaftarannya telah menjadi efektif wajib menyampaikan laporan tahunan kepada Bapepam dan LK paling lama 4 (empat) bulan setelah tahun buku berakhir. Hasil audit atas laporan keuangan perusahaan wajib diumumkan ke publik minimal melalui 2 surat kabar harian berbahasa Indonesia. 


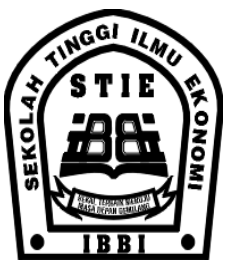

Audit laporan keuangan untuk perusahaan go public biasanya dilakukan oleh auditor independen, untuk lebih meyakinkan publik bahwa laporan auditan yang dihasilkan bias dari campur tangan dan pengaruh dari pihak internal perusahaan. Kualitas auditor independen juga menjadi salah satu faktor penentu atas keakuratan dan kehandalan sebuah laporan auditan perusahaan.

Sama halnya dengan ketepatan waktu penyelesaian laporan keuangan perusahaan, laporan keuangan auditan yang dikerjakan auditor juga harus tepat waktu dalam proses penyampaiannya sesuai dengan standar yang berlaku. Tetapi laporan auditan yang dikerjakan oleh auditor jika benar-benar sesuai dengan standar akan menghabiskan waktu yang cukup lama karena adanya peraturan tentang prosedur dalam penyelesaian pekerjaan lapangan (IAI, 2001), seperti perencanaan atas aktivitas yang dilakukan, pemahaman yang memadai atas struktur pengendalian intern dan pengumpulan buktibukti kompeten yang diperoleh melalui inspeksi, pengamatan, pengajuan pertanyaan dan konfirmasi sebagai dasar untuk menyatakan pendapat atas laporan keuangan.

Adanya perbedaan waktu antara tanggal laporan keuangan dengan tanggal keluarnya laporan audit independen (opini audit) menunjukkan lamanya waktu penyelesaian audit yang dilakukan oleh auditor. Perbedaan waktu antara tanggal laporan keuangan dengan tanggal keluarnya laporan auditor independen dikenal dengan istilah audit delay atau rentang waktu penyelesaian proses audit.

Masih banyaknya kasus keterlambatan penyampaian laporan keuangan tahunan yang terjadi di Indonesia, menarik perhatian banyak pihak termasuk para peneliti. Seperti kasus yang terjadi pada tahun 2012 yang dimuat dalam sebuah website tanggal 3 April 2013 dimana ada dua emiten di Bursa Efek Indonesia (BEI) yang menyatakan ketidaksanggupannya menyampaikan laporan keuangan tahun 2012 yang seharusnya diserahkan pada akhir Maret 2013 dan mempublikasikannya pada surat kabar nasional. Kedua emiten tersebut adalah PT Bank Mutiara Tbk (BCIC) dan PT Energi Mega Persada Tbk (ENRG). Alasan atas keterlambatan penyampaian laporan keuangan kedua emiten tersebut yakni laporan keuangan perseroan masih dalam proses review oleh kantor akuntan publik terhadap beberapa pos atas laporan keuangan tersebut. Pada tanggal 30 Juni 2014 diberitakan bahwa manajemen PT BEI menghentikan sementara perdagangan saham lima emiten lantaran terlambat menyampaikan laporan keuangan 2013 hingga tanggal 29 Juni 2014 dan denda atas keterlambatan tersebut. Lima emiten itu antara lain PT Berlian Laju Tanker Tbk (BLTA) yang belum menyampaikan laporan keuangan auditan 2013 dan pembayaran denda. Begitu pula dengan PT Borneo Lumbung Energi dan Metal Tbk (BORN), PT Buana Listya Tama Tbk (BULL), PT Truba Alam Manunggal Engineering Tbk (TBLA) dan PT Tri Banyan Tirta Tbk (ALTO).Diantara kelima emiten tersebut ada yang mengungkapkan alasan atas keterlambatannya dalam menyampaikan laporan keuangan kepada BEI dan BAPEPAM, dan ada pula yang tidak mengungkapkan alasannya (www.liputan6.com).

Penelitian dengan tema audit delay sudah banyak dilakukan oleh peneliti sebelumnya, seperti penelitian yang dilakukan Kartika (2009) menemukan bahwa faktor aset, laba rugi operasi, mempunyai pengaruh negatif dan signifikan terhadap audit delay dan opini auditor memiliki pengaruh positif dan signifikan terhadap audit delay, sedangkan faktor profit dan reputasi auditor tidak mempunyai pengaruh terhadap audit delay. Berbeda dengan hasil penelitian yang dilakukan Angruningrum \& Wirakusuma (2013) yang menemukan bahwa variabel yang berpengaruh terhadap audit delay yaitu leverage, sedangkan untuk variabel lainnya yaitu profitabilitas, kompleksitas operasi perusahaan, reputasi KAP, dan komite audit tidak mempengaruhi audit delay.Penelitian Hosain (1998) dalam Kartika (2011) menemukan faktor yang berbeda yaitu adanya cabang perusahaan untuk perusahaan 


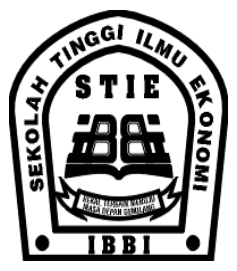

multinasional yang dapat mempengaruhi audit delay.

Dari beberapa faktor-faktor tersebut, faktor internal yang akan diuji kembali salah satunya yaitu ukuran perusahaan. Ukuran perusahaan menunjukkan besar kecilnya sebuah perusahaan yang dapat dilihat berdasarkan total aset dan total pendapatan dalam satu periode. Menurut Kusumawardani (2013) ukuran perusahaan berpengaruh terhadap audit delay. Seperti yang dikemukakan oleh Hossain dan Taylor dalam penelitian Puspitasari dan Sari (2012) bahwa perusahaan yang mempunyai total aset yang lebih besar akan menyelesaikan audit lebih lama dibandingkan dengan perusahaan yang mempunyai total aset yang lebih kecil.

Faktor internal selanjutnya yaitu umur perusahaan, yang diukur berdasarkan lamanya perusahaan tersebut berdiri (dalam tahun).Menurut Owushu-Ansah dalam Petrolina (2007) menemukan bahwa adanya pengaruh positif antara umur perusahaan dengan audit delay. Sedangkan Courtis dalam Petrolina (2007) menyatakan bahwa umur perusahaan tidak berpengaruh terhadap audit report lag.

Berikutnya yaitu kompleksitas operasi perusahaan, yang diukur berdasarkan ada tidaknya anak perusahaan yang dimiliki perusahaan apakah mempengaruhi audit delay.Menurut penelitian Angruningrum \& Wirakusuma(2013) dan penelitian Latifa(2015) menemukan bahwa kompleksitas operasi perusahaan tidak mempengaruhi audit delay.

Faktor eksternal yang akan diuji kembali yaitu reputasi KAP (Kantor Akuntan Publik). Menurut Kartika (2011) Kantor Akuntan Publik yang bereputasi baik, diperkirakan dapat melakukan audit lebih efisien dan memiliki fleksibilitas yang lebih besar untuk menyelesaikan audit sesuai jadwal. Sejalan dengan penelitian Angruningrum \& Wirakusuma (2013) yang menyatakan bahwa ukuran KAP berpengaruh signifikan terhadap audit delay.

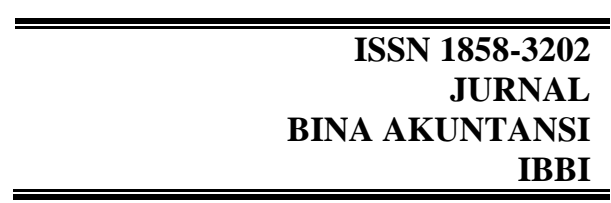

Faktor eksternal selanjutnya adalah opini audit. Opini audit merupakan pendapat yang diberikan auditor sebagai hasil dari pengauditan laporan keuangan perusahaan (klien). Hasil penelitian Apriliane(2015) dan Kartika (2009) menemukan bahwa opini auditor punya pengaruh positif dan signifikan terhadap audit delay. Tetapi pada penelitian Kartika (2011) menunjukkan hasil berbeda yang menemukan bahwa opini auditor tidak memiliki pengaruh terhadap audit delay.

Berdasarkan pada penelitian sebelumnya yang sangat bervariasi hasilnya dan juga masih ditemukannya perusahaan yang terlambat menyampaikan laporan keuangan akibat audit delay, maka peneliti tertarik untuk meneliti kembali dan mengembangkan penelitian terdahulu yang dilakukan oleh Kartika (2011), Puspitasari dan Sari (2012), Angruningrum dan Wirakusuma (2013), Sa'adah (2013), serta Latifa (2015).

Penelitian ini mengambil sampel pada perusahaan LQ 45, karena perusahaanperusahaan yang termasuk kedalam LQ 45 merupakan perusahaan yang sahamnya memiliki tingkat likuiditas dan kapitalisasi pasar yang tinggi (Latifa, 2015:4), dan juga merupakan perusahaan dengan urutan tertinggi yang mewakili sektornya dalam klasifikasi industri Bursa Efek Indonesia. BEI secara rutin memantau perkembangan kinerja komponen emiten-emiten/saham yang masuk dalam penghitungan indeks LQ 45. BEI dalam setiap tiga bulan sekali melakukan evaluasi atas pergerakan urutan emiten-emiten tersebut, dan mengganti daftarnya setiap 6 bulan sekali atau per semester. Peneliti ingin mengetahui berapa lama waktu antara tanggal laporan keuangan yang diterbitkan dengan tanggal keluarnya hasil audit pada kasus perusahaan LQ 45. Oleh karena itu peneliti tertarik untuk mengambil sampel penelitian pada perusahaan LQ 45.

\section{KAJIAN LITERATUR DAN PENGEMBANGAN HIPOTESIS}

Audit delay 


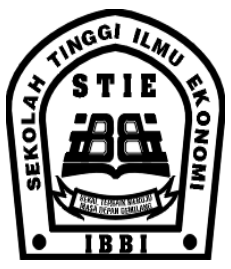

Audit delay merupakan

lamanya/rentang waktu penyelesaian audit yang diukur dari tanggal penutupan tahun buku sampai dengan tanggal diterbitkannya laporan audit. Audit delay inilah yang dapat mempengaruhi ketepatan informasi yang dipublikasikan, sehingga akan berpengaruh terhadap tingkat ketidak pastian keputusan yang berdasarkaninformasi yang dipublikasikan(Kartika, 2011). Menurut Lawrence dan Briyan dalam (Yulianti, 2011)audit delay adalah lamanya hari yang dibutuhkan auditor untuk menyelesaikan pekerjaan auditnya, yang diukur dari tanggal penutupan tahun buku hingga tanggal diterbitkannya laporan keuangan audit.

Dalam penelitian Subekti dan Widiyanti (2004), perbedaan waktu yang sering dinamai dengan audit delay adalah perbedaan antara tanggal laporan keuangan dengan tanggal opini audit dalam laporan keuangan yang mengindikasikan tentang lamanya waktu penyelesaian audit yang dilakukan oleh auditor. Semakin lama auditor menyelesaikan pekerjaan auditnya, maka semakin panjang audit delay yang terjadi.

Audit delay juga dikenal dengan istilah audit report lag. Namun untuk pengukuran untuk audit delay belum bisa dipastikanhanya dari tanggal tutup buku perusahaan, karena penyampaian laporan keuangan tahunan perusahaan oleh manajer kepada auditor independen yang berbeda-beda untuk masingmasing perusahaan setiap tahunnya.

Audit delay dalam penelitian ini adalah jumlah hari/waktu yang diperlukan auditor dalam menyelesaikan proses audit atas laporan keuangan perusahaan yang terhitung sejak tanggal penutupan tahun buku yakni 31 Desember sampai tanggal yang tertera dalam laporan auditor independen.

\section{Ukuran Perusahaan}

Besar kecilnya ukuran perusahaan juga dipengaruhi oleh kompleksitas operasional, variablititas dan intensitas

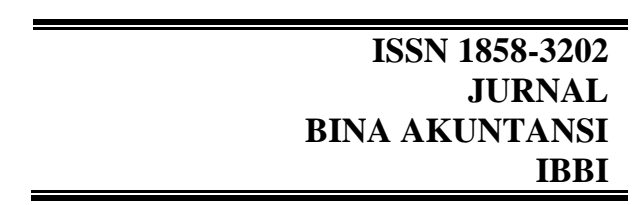

transaksi perusahaan tersebut yang akan berpengaruh terhadap kecepatan dalam menyajikan laporan keuangan kepada publik. Ukuran perusahaan yang menunjukkan besar kecilnya sebuah perusahaan dapat dilihat berdasarkan total aset dan total pendapatan dalam satu periode. Menurut Keputusan Ketua BAPEPAM-LK No. Kep. 11/PM/1997 perusahaan kecil dan menengah berdasarkan aktiva (kekayaan) adalah badan hukum yang memiliki total aktiva tidak lebih dari seratus milyar, sedangkan perusahaan besar adalah badan hukum yang total aktivanya diatas seratus milyar (Yulianti, 2011).

Menurut Kartika (2011) semakin besar ukuran perusahaan maka audit delaynya semakin pendek dansebaliknya. Perusahaan besar diduga akan menyelesaikan proses auditnya lebih cepat dibandingkan perusahaan kecil. Hal ini disebabkan oleh beberapa factor yaitu manajemen perusahaan yang berskala besar cenderung diberikan insentif untuk mengurangi audit delay dikarenakan perusahaan tersebut dimonitor secara ketat oleh investor, pengawas permodalan, dan pemerintah. Berbeda dengan penelitian Hossain dan Taylor dalam penelitian Puspitasari dan Nurmalasari (2012:33) yang menyatakan bahwa perusahaan yang mempunyai total aset yang lebih besar akan menyelesaikan audit lebih lama dibandingkan dengan perusahaan yang mempunyai total aset yang lebih kecil, hal ini dikarenakan jumlah sampel yang harus diambil semakin besar dan semakin banyak prosedur audit yang harus ditempuh.

Ukuranperusahaandalampenelitianinia dalah jumlah aset yang dimiliki perusahaan yang tercantum dalam laporan keuangan perusahaan pada akhir periode dengan menggunakan rumus logaritma natural (Ln).

\section{Umur Perusahaan}

Umur perusahaan dihitung mulai dari tanggal pertama kali didirikannya perusahaan tersebut di BEI hingga akhir tahun periode 


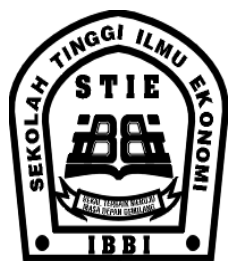

penelitian. Menurut Indra dan Arisudhana (2012) semakin lama umur suatu perusahaan maka semakin pendek audit report lag perusahaan tersebut. Hal ini dikarenakan perusahaan yang telah lama berdiri dinilai lebih mampu dan telah berpengalaman dalam mengumpulkan, memproses, dan menghasilkan informasi yang dibutuhkan dalam proses audit. Namun, Owushu-Ansah dalam Petrolina (2007) menemukan bahwa adanya pengaruh positif antara umur perusahaan dengan audit delay. Sedangkan Courtis dalam Petrolina (2007) menyatakan bahwa umur perusahaan tidak berpengaruh terhadap audit report lag.

Umur perusahaan dalam penelitian ini adalah jumlah tahun mulai daripertama kali didirikannya perusahaan tersebut hingga akhir tahun periode dalam penelitian ini yang mengindikasikan sudah berapa lama perusahaan tersebut didirikan.

\section{Kompleksitas Operasi Perusahaan}

Tingkat kompleksitas operasi sebuah perusahaan yang bergantung pada jumlah dan lokasi unit operasinya (cabang) serta diversifikasi jalur produk dan pasarnya, lebih cenderung mempengaruhi waktu yang dibutuhkan auditor untuk menyelesaikan pekerjaan auditnya (Apriliane, 2015:28). Menurut Widosari dan Rahardja (2012) dalam penelitian Latifa (2015:6) jumlah anak perusahaan suatu perusahaan mewakili kompleksitas jasa audit yang diberikan yang merupakan ukuran rumit atau tidaknya transaksi yang dimiliki oleh klien KAP untuk diaudit. Selain itu apabila perusahaan memiliki anak perusahaan diluar negeri maka laporan tambahan yang perlu diaudit adalah laporan reasurement (Latifa, 2015:6).

Perusahaan yang memiliki anak perusahaan akan mengkonsolidasikan laporan keuangannya, yang selanjutnya akan diaudit oleh auditor. Dengan demikian akan menambah ruang lingkup kerja auditor yang

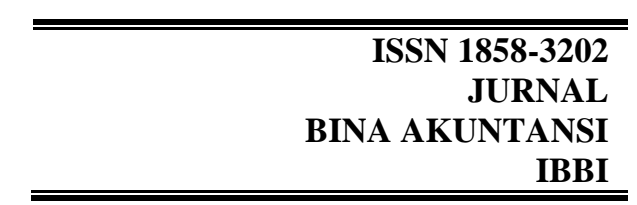

berakibat kepada lamanya waktu penyelesaian audit (audit delay).

Kompleksitas operasi perusahaan dalam penelitian ini yaitu jumlah anak perusahaan yang dimiliki oleh perusahaan tersebut. Keberadaan anak perusahaan yang cukup banyak diperkirakan akan memperumit pekerjaan audit yang dilakukanoleh auditor.

\section{Reputasi KAP}

\begin{abstract}
Menurut Kartika (2011:158) Kantor Akuntan Publik yang bereputasi baik, diperkirakan dapat melakukan audit lebih efisien dan memiliki fleksibilitas yang lebih besar untuk menyelesaikan audit sesuai jadwal. Sehingga informasi dapat lebih cepat diterima pengguna laporan keuangan dalam pengambilan keputusan. Kantor Akuntan Publik (KAP) adalah suatu bentuk organisasi akuntan publik yang memperoleh izin sesuai dengan peraturan perundang-undangan yang berusaha di bidang pemberian jasa profesional dalam praktek akuntan publik.
\end{abstract}

Perusahaan klien yang ingin mendapatkan jasa auditor dengan kualitas baik tentunya berasal dari Kantor Akuntan Publik yang memiliki reputasi yang baik juga. Karena, Kantor Akuntan Publik yang bereputasi baik diperkirakan dapat melakukan audit lebih efisien dan efektif dalam menyelesaikan audit. Ahmad dan Kamarudin (2003) dalam Apriliane (2015:32) menemukan bahwa audit delay pada KAP Big Four akan lebih pendek dibandingkan dengan KAP non Big Four. Menurut BEI, Kantor Akuntan Publik (KAP) terbaik yang sering disebut dengan "The Big Four" yang berafiliasi di Indonesia, yakni :

1. KAP Tanudiredja, Wibisana \& Rekan bersama Price Waterhouse Cooper (PWC).

2. KAP Purwantono, Suherman dan Surja bersama Ernst \& Young (EY).

3. KAP Osman Bing Satrio bersama Deloitte Touche Tohmatsu (DTT). 


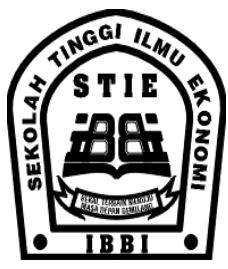

4. KAP Siddharta dan Widjaja bersama Klynveldt Pield Marwick Goerdeler (KMPG).

Reputasi KAP dalam penelitian ini merupakan KAP mana yang dipakai oleh perusahaan untukmengauditlaporankeuangannya, apakah KAP tersebutmerupakan KAP Big Fouratautidak.

\section{Opini Audit}

Laporan auditor merupakan sarana bagi auditor untuk menyatakan pendapatnya. Baik dalam hal auditor menyatakan pendapatnya maupun menyatakan tidak memberikan pendapat, auditor harus menyatakan apakah auditnya telah dilaksanakan berdasarkan standard auditing. Standar auditing mengharuskan auditor menyatakan apakah menurut pendapatnya laporan keuangan disajikan sesuai dengan prinsip akuntansi yang berlaku umum ataukah tidak (Rahayu \& Suhayati, 2010:93).

Menurut Kartika (2011) semakin besar ukuran perusahaan maka audit delaynya semakin pendek dansebaliknya. Perusahaan besar diduga akan menyelesaikan proses auditnya lebih cepat dibandingkan perusahaan kecil. Hal ini disebabkan oleh beberapa factor yaitu manajemen perusahaan yang berskala besar cenderung diberikan insentif untuk mengurangi audit delay dikarenakan perusahaan tersebut dimonitor secara ketat oleh investor, pengawas permodalan, dan pemerintah. Hal ini menunjukkan bahwa ukuran perusahaan berpengaruh negatif terhadap audit delay.

Menurut Indra dan Arisudhana (2012) bahwa semakin lama umur suatu perusahaan maka semakin pendek audit report lag perusahaan tersebut. Hal ini dikarenakan perusahaan yang telah lama berdiri dinilai lebih mampu dan telah berpengalaman dalam mengumpulkan, memproses, dan menghasilkan informasi yang dibutuhkan dalam proses audit, sehingga dapat

\section{ISSN 1858-3202 \\ JURNAL \\ BINA AKUNTANSI \\ IBBI}

mempercepat proses audit. Hal ini menunjukkan bahwa umur perusahaan berpengaruh negatif terhadap audit delay.

Tingkat kompleksitas operasi sebuah perusahaan yang bergantung pada jumlah dan lokasi unit operasinya (cabang) serta diversifikasi jalur produk dan pasarnya, lebih cenderung mempengaruhi waktu yang dibutuhkan auditor untuk menyelesaikan pekerjaan auditnya (Apriliane, 2015:28). Menurut Widosari dan Rahardja (2012) dalam penelitian Latifa (2015:6) jumlah anak perusahaan suatu perusahaan mewakili kompleksitas jasa audit yang diberikan yang merupakan ukuran rumit atau tidaknya transaksi yang dimiliki oleh klien KAP untuk diaudit. Hal ini menunjukkan bahwa kompleksitas operasi perusahaan berpengaruh positif terhadap audit delay.

Perusahaan klien yang ingin mendapatkan jasa auditor dengan kualitas baik tentunya berasal dari KAP yang memiliki reputasi yang baik juga. Karena, KAP yang bereputasi baik diperkirakan dapat melakukan audit lebih efisien dan efektif dalam menyelesaikan audit.Ahmad dan Kamarudin (2003:14) dalam Apriliane (2015:32) menemukan bahwa audit delay pada KAP Big Four akan lebih pendek dibandingkan dengan KAP non - Big Four. Hal ini menunjukkan bahwa reputasi KAP berpengaruh negatif terhadap audit delay.

Perusahaan yang menerima jenis pendapat qualified opinion akan menunjukkan audit delay yang relatif lama, karena proses pemberian opini audit melibatkan negoisasi dengan klien, konsultasi dengan partner audit yang lebih senior atau staf teknis lainnya dan perluasan lingkup audit (Apriliane, 2015:46). Sebaliknyaapabilaperusahaanmenerimapendap atunqualified opinion, makaaudit delayakansemakinpendek. Hal ini menunjukkan bahwa opini audit berpengaruh negatif terhadap audit delay.

\section{METODE PENELITIAN}

Variabel Dependen (Y) 


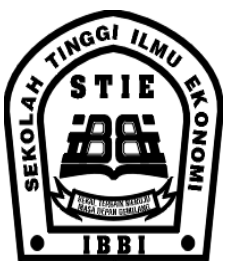

Variabel dependen adalah variabel yang dipengaruhi oleh variabel lain. Variabel dependen dalam penelitian ini adalah audit delay. Audit delay adalah lamanya waktu yang dibutuhkan auditor dalam menyelesaikan audit. Pengukurannya secara kuantitatif yaitu dari tanggal berakhirnya tahun bukuperusahaan (31 Desember) hingga tanggal yang tercantum dalam laporan auditor independen.

\section{Variabel Independen (X)}

Variabel independen adalah variabel yang mempengaruhi variabel lain. Variabel dalam penelitian ini ada lima yaitu :

\section{Ukuran Perusahaan $\left(\mathbf{X}_{1}\right)$}

Ukuran perusahaan dalam penelitian ini diukur berdasarkan total aset yaitu jumlah aset yang dimiliki perusahaan klien yang tercantum dalam laporan keuangan perusahaan pada akhir periode dengan menggunakan rumus logaritma natural (Ln). Penggunaan logaritma natural dalam mengukur nilai total aset dikarenakan banyaknya jumlah asetdalam sebuah perusahaan, termasuk aset lancar maupun aset tetap. Dengan menggunakan log, akan lebih memudahkan dalam melalukan pengukuran tanpa mengubah nilai asli aset.

\section{Umur Perusahaan $\left(X_{2}\right)$}

Umur perusahaan dalam penelitian ini diukur dalam satuan tahun yang dihitung mulai dari tahun perusahaan tersebut berdiri sampai dengan akhir tahun periode penelitian ini yaitu tahun 2014

\section{Kompleksitas Operasi Perusahaan $\left(\mathbf{X}_{3}\right)$}

Kompleksitas operasi perusahaan dalam penelitian ini diukur dalam satuan jumlah perusahaan yang menunjukkan jumlah anak perusahaan yang dimiliki oleh perusahaan sampel.

\section{Reputasi KAP $\left(\mathrm{X}_{4}\right)$}

Reputasi KAP merupakan pandangan atas nama baik, prestasi dan kepercayaan publik yang disandang KAP. Dalam penelitian ini reputasi KAP diukur dengan menggunakan dummy, yaitu KAP big fourdiberi kode 1, sedangkan KAP non - big four diberi kode 0 .

\section{Opini Audit ( $\left.\mathbf{X}_{5}\right)$}

Opini audit merupakan opini yang diberikan oleh auditor independen sebagai penilaian berupa pernyataan atas kewajaran laporan keuangan yang telah diaudit oleh auditor berdasarkan standar auditing yang berlaku. Ada lima jenis opini audit yang diberikan oleh auditor kepada perusahaan klien. Dalam penelitian ini dibagi menjadi dua yaitu unqualified opinion dan opini selain unqualified opinion. Variabel ini diukur dengan dummy, yaitu untuk opini selain unqualified opinion diberi kode 0 dan untuk unqulified opinion diberi kode 1.

\section{Populasi Penelitian}

Populasi adalah keseluruhan data yang akan diamati dan diteliti terhadap orang, benda atau tempat yang memiliki kriteria tertentu, sedangkan sampel yaitu bagian dari populasi. Populasi dalam penelitian ini adalah perusahaan yang termasuk dalam perusahaan LQ 45 di Bursa Efek Indonesia (BEI) periode 2013-2014. Populasi dalam penelitian ini sebanyak 31 dari 45 perusahaan yang memenuhi kriteria populasi. Kriteria dalam menentukan populasi adalah:

1. Perusahaan LQ 45 yang termasuk dan terdaftar secara berturut-turut sebagai perusahaan LQ 45 di BEI selama periode 2013-1014.

2. Perusahaan LQ 45 yang telah menyampaikan laporan keuangan tahunan untuk tahun 2013-2014 dimana didalamnya terdapat data dan informasi yang dapat digunakan dalam penelitian ini.

3. Perusahaan LQ 45 yang laporan keuangan tahunannya telah diaudit dan disertai laporan auditor.

Berdasarkan kriteria tersebut maka perusahaan yang terdaftar dalam indeks LQ45 yang memenuhi syarat dalam penelitian ini adalah 


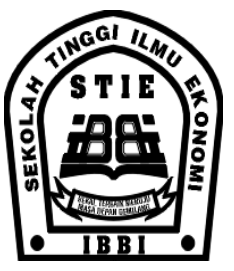

sebanyak 31 perusahaan, selama 2 tahun penelitian (2013-2014) sehingga terdapat 62 pengamatan.

Pengujian hipotesis dilakukan dengan analisis multivariat dengan menggunakan regresi berganda (multiple regression), karena variabel independennya berjumlah lebih dari 1variabel. Sedangkan model regresi yang digunakan untuk menguji hipotesis yakni:

$Y=a_{0}+a_{1} X_{1}+a_{2} X_{2}+a_{3} X_{3}+a_{4} X_{4}+a_{5} X_{5}+\varepsilon$ Keteragan :

$\mathrm{Y} \quad=$ Audit Delay

$\mathrm{X}_{1} \quad=$ Ukuran Perusahaan

$\mathrm{X}_{2} \quad=$ Kompleksitas Operasi Perusahaa

$\mathrm{X}_{3} \quad=$ Umur Perusahaan

$\mathrm{X}_{4} \quad=$ Reputasi KAP

$\mathrm{X}_{5} \quad=$ Opini Audit

$\mathrm{a}_{0} \quad=$ Konstanta

$\mathrm{a}_{1}-\mathrm{a}_{5}=$ Koefisien regresi

$\varepsilon \quad=$ Pengaruh varb.lain

\section{HASIL DAN PEMBAHASAN}

Sampel dalam penelitian ini adalah perusahaan LQ45 yang terdaftar di Bursa Efek Indonesia (BEI) selama periode 2013-2014 (2 tahun). Berdasarkan kriteria yang telah ditentukan dengan menggunakan metode purposive sampling, maka sampel yang diperoleh yaitu sebanyak 31 perusahaan LQ45 yang terdaftar di BEI selama tahun 2013-2014, sehingga jumlah sampel total menjadi sebanyak 62 perusahaan.

1. Distribusi Sampel Berdasarkan Ukuran Perusahaan

\begin{tabular}{|l|l|l|l|}
\hline No. & $\begin{array}{l}\text { Ukuran } \\
\text { Perusahaan/Total } \\
\text { Aset } \\
\text { (Jutaan Rupiah) }\end{array}$ & Jumlah & Persentase \\
\hline 1 & $<10.000 .000$ & 5 & $8,1 \%$ \\
\hline 2 & $\begin{array}{l}10.000 .000- \\
100.000 .000\end{array}$ & 43 & $69,3 \%$ \\
\hline
\end{tabular}

ISSN 1858-3202

JURNAL

BINA AKUNTANSI

IBBI

\begin{tabular}{|l|l|l|l|}
\hline 3 & $>100.000 .000$ & 14 & $22,6 \%$ \\
\hline Total & 62 & $100 \%$ \\
\hline
\end{tabular}

Sumber: data diolah, 2016

Distribusi sampel berdasarkan tabel 4.1, menunjukkan bahwa hanya $8,1 \%$ dari total sampel yang memiliki total aset dibawah 10.000.000, sebesar $69,3 \%$ sampel memiliki total aset direntang $>10.000 .000-100.000 .000$, dan $22,6 \%$ dari sampel yang memiliki total aset diatas 100.000.000.

2. Distribusi Sampel Berdasarkan Umur Perusahaan

\begin{tabular}{|l|l|l|l|}
\hline No. & $\begin{array}{l}\text { Umur Perushaan } \\
\text { (Tahun) }\end{array}$ & Jumlah & Persentase \\
\hline 1 & $<50$ & 46 & $74,2 \%$ \\
\hline 2 & $51-100$ & 14 & $22,6 \%$ \\
\hline 3 & $101-150$ & 0 & $0 \%$ \\
\hline 4 & $>150$ & 2 & $3,2 \%$ \\
\hline \multicolumn{2}{|l|}{ Total } & 62 & $100 \%$ \\
\hline
\end{tabular}

Sumber: data diolah, 2016

Berdasarkan tabel 4.2, dapat dilihat bahwa sebesar $74,2 \%$ perusahaan memiliki umur dibawah 50 tahun, dan hanya 3,2\% perusahaan yang umurnya diatas 150 tahun.

3. Distribusi Sampel Berdasarkan Kompleksitas Operasi Perusahaan

\begin{tabular}{|l|l|l|l|}
\hline No. & $\begin{array}{l}\text { Kompleksitas } \\
\text { Operasi } \\
\text { Perushaan } \\
\text { (Entitas Anak) }\end{array}$ & Jumlah & Persentase \\
\hline 1 & $1-100$ & 58 & $93,6 \%$ \\
\hline 2 & $101-200$ & 2 & $3,2 \%$ \\
\hline 3 & $>200$ & 2 & $3,2 \%$ \\
\hline
\end{tabular}




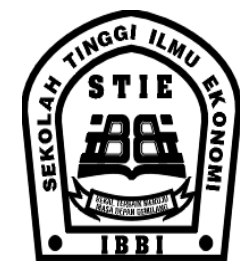

\begin{tabular}{|l|l|l|}
\hline Total & 62 & $100 \%$ \\
\hline
\end{tabular}

Sumber: data diolah, 2016

Distribusi sampel berdasarkan tabel 4.3, menunjukkan bahwa mayoritas perusahaan sampel sebesar 93,6\% memiliki entitas anak dibawah 100 entitas anakperusahaan.

4. Distribusi Sampel Berdasarkan Reputasi KAP

\begin{tabular}{|l|l|l|l|}
\hline No. & $\begin{array}{l}\text { Reputasi KAP } \\
\text { (Kode) }\end{array}$ & Jumlah & Persentase \\
\hline 1 & 0 & 8 & $12,9 \%$ \\
\hline 2 & 1 & 54 & $87,1 \%$ \\
\hline \multicolumn{2}{|l|}{ Total } & 62 & $100 \%$ \\
\hline
\end{tabular}

Ket: 0 = non-BigFour $; 1=$ BigFour

Sumber: data diolah, 2016

Berdasarkan tabel 4.4, dapat dilihat bahwa perusahaan sampel lebih banyak menggunakan KAP BigFour yaitu sebesar $87,1 \%$ daripada KAP non-Big Four yang hanya sebesar $12,9 \%$.

5. Distribusi Sampel Berdasarkan Opini Audit

\begin{tabular}{|l|l|l|l|}
\hline No. & $\begin{array}{l}\text { Opini Audit } \\
\text { (Kode) }\end{array}$ & Jumlah & Persentase \\
\hline 1 & 0 & 26 & $41,9 \%$ \\
\hline 2 & 1 & 36 & $58,1 \%$ \\
\hline \multicolumn{2}{|l|}{ Total } & 62 & $100 \%$ \\
\hline
\end{tabular}

Ket: $0=$ Selain Unqualified Opinion ; $1=$ Unqualified Opinion

\section{Sumber: data primer diolah, 2016}

Distribusi sampel berdasarkan tabel 4.5, menunjukkan bahwa sebanyak $58,1 \%$ perusahaan mendapatkan unqualified opinion dan sebesar $41,9 \%$ perusahaan sampel yang mendapatkan opini selain unqualified opinion.

\begin{tabular}{|l|l|l|l|l|l|}
\hline Variabel & $\mathbf{N}$ & $\begin{array}{l}\text { Minimu } \\
\mathbf{m}\end{array}$ & $\begin{array}{l}\text { Maxim } \\
\mathbf{u m}\end{array}$ & $\begin{array}{l}\text { Mea } \\
\mathbf{n}\end{array}$ & $\begin{array}{l}\text { Std. } \\
\text { Devia } \\
\text { tion }\end{array}$ \\
\hline $\begin{array}{l}\text { AUDELAY } \\
\text {-Y }\end{array}$ & 62 & 16,00 & 89,00 & $\begin{array}{l}58,4 \\
355\end{array}$ & $\begin{array}{l}19,90 \\
191\end{array}$ \\
\hline SIZE_X1 & 62 & 29,32 & 34,38 & $\begin{array}{l}31,4 \\
082\end{array}$ & $\begin{array}{l}1,337 \\
07\end{array}$ \\
\hline YEAR_X2 & 62 & 4.00 & 155,00 & $\begin{array}{l}39,7 \\
258\end{array}$ & $\begin{array}{l}27,54 \\
381\end{array}$ \\
\hline $\begin{array}{l}\text { KOMPLEK } \\
\text { _X3 }\end{array}$ & 62 & 1,00 & 317,00 & $\begin{array}{l}31,5 \\
484\end{array}$ & $\begin{array}{l}56,22 \\
953\end{array}$ \\
\hline $\begin{array}{l}\text { RKAP_X4 } \\
\text { Y2 }\end{array}$ & 0 & 1 & 0,87 & 0,338 \\
\hline OPINI_X5 & 62 & 0 & 1 & 0,58 & 0,497 \\
\hline $\begin{array}{l}\text { Valid N } \\
\text { (listwise) }\end{array}$ & 62 & & & & \\
\hline
\end{tabular}

Sumber: data diolah, 2016

\section{Audit Delay}

Berdasarkan tabel 4.6 yang menunjukkan mean (rata-rata) dari audit delay yang terjadi pada perusahaan LQ45 tahun 2013-2014 adalah sebesar 58,4355 hari dengan standar deviasi 19,90191. Audit delay minimum yang terjadi adalah 16 hari dan maksimum 89 hari. Perusahaan yang memiliki nilai audit delay terendah dalam penelitian ini adalah PT Bank Rakyat Indonesia (Persero) Tbk pada tahun 2013-2014 dan PT Bank Danamon Tbk pada tahun 2014, sedangkan perusahaan yang memiliki nilai audit delay tertinggi dalam penelitian ini adalah PT Harum Energy Tbk pada tahun 2014.

\section{Ukuran Perusahaan}

Ukuran perusahaan yang dilihat berdasarkan total asset mempunyai rentang nilai antara log 29,32 sampai dengan log 34,38 dengan ratarata (mean) sebesar log 31,4082 dan standar deviasi 1,33707. Perusahaan yang memiliki ukuran perusahaan dengan nilai tertinggi dalam penelitian ini adalah PT Bank Mandiri (Persero) Tbk pada tahun 2014, sedangkan 


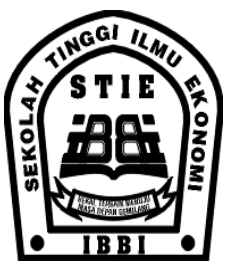

perusahaan yang memiliki nilai ukuran perusahaan terendah adalah PT Harum Energy Tbk pada tahun 2014.

\section{Umur Perusahaan}

Hasil analisis deskriptif variabel umur perusahaan dalam penelitian ini diperoleh nilai rata-rata sebesar 39,7258dengan standar deviasi 27,54381, dannilai tertinggi sebesar 155 tahun yakni PT Perusahaan Gas Negara (Persero) Tbk, sedangkan nilai terendah adalah 4 tahun yakni PT Indofood CBP Sukses Makmur Tbk.

\section{Kompleksitas Perusahaan}

Operasi

Variabel kompleksitas operasi perusahaan diukur berdasarkan jumlah anak perusahaan yang dimiliki oleh perusahaan sampel.Hasil analisis deskriptif menunjukkan nilai rata-rata sebesar 31,5484 dengan standar deviasi 56,22953, nilai tertinggi sebesar 317 anak perusahaan, sedangkan nilai terendah yaitu 1 perusahaan.

\section{Reputasi KAP}

Reputasi KAP dalam penelitian ini dibagi menjadi dua kategori yakni KAP non-Big Four dan KAP Big Four yang diukur dengan menggunakan variabel dummy. Hasil analisis deskriptif variabel reputasi KAP diperoleh nilai rata-rata 0,87 dengan standar deviasi 0,338 .

\section{Statistik Deskriptif Reputasi KAP}

\begin{tabular}{|l|l|l|}
\hline Keterangan & Jumlah & Persentase \\
\hline KAP non-Big Four & 8 & $12,9 \%$ \\
\hline KAP Big Four & 54 & $87,1 \%$ \\
\hline Total & 62 & $100 \%$ \\
\hline Sumber: data sekunder diolah 2016
\end{tabular}
(terlampir)

Berdasarkan tabel 4.7 dapat dilihat bahwa $87,1 \%$ perusahaan sampel diaudit oleh KAP Big Four dan 12,9\% diaudit oleh KAP non-Big Four.

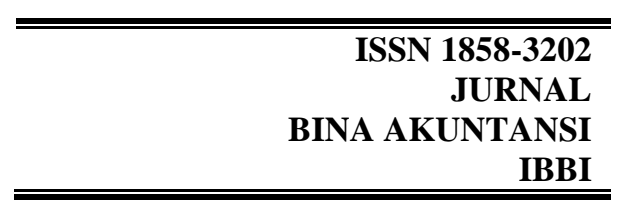

\section{Opini Audit}

Dalam penelitian ini opini audit dibagi menjadi dua kategori yakni opini selain unqualified opinion dan unqualified opinion. Hasil analisis statistik deskriptif opini audit perusahaan diperoleh nilai rata-rata 0,58 dengan standar deviasi sebesar 0,497.

\begin{tabular}{|l|l|l|}
\hline Keterangan & Jumlah & Persentase \\
\hline $\begin{array}{l}\text { Selain unqualified } \\
\text { opinion }\end{array}$ & 26 & $41,9 \%$ \\
\hline unqualified opinion & 36 & $58,1 \%$ \\
\hline Total data sekunder diolah, 2016 \\
\hline
\end{tabular}

(terlampir)

Hasil penelitian menunjukkan bahwa $58,1 \%$ dari perusahaan sampel menerima opini unqualified opinion dan $41,9 \%$ menerima opini selain unqualified opinion.

\section{Pengujian Analisis Regresi Berganda}

\section{Hasil Analisis Regresi Linier Berganda}

\begin{tabular}{|l|l|l|l|}
\hline Variabel & Koefisien Regresi (B) & $\mathbf{t}_{\text {hitung }}$ & Sig. \\
\hline Konstanta & 324,526 & 6,672 & 0,000 \\
\hline $\mathrm{X}_{1}$ & $-8,890$ & $-5,712$ & 0,000 \\
\hline $\mathrm{X}_{2}$ & $-0,056$ & $-0,726$ & 0,471 \\
\hline $\mathrm{X}_{3}$ & 0,114 & 2,748 & 0,008 \\
\hline $\mathrm{X}_{4}$ & 18,039 & 2,595 & 0,012 \\
\hline $\mathrm{X}_{5}$ & $-6,841$ & $-1,616$ & 0,112 \\
\hline $\mathrm{R}^{2}=0,427$ & & & \\
\hline Adj. ${ }^{2}=0,376$ & & \\
\hline $\mathrm{t}_{\text {tabel }}=1,673$ & & \\
\hline $\mathrm{F}_{\text {hitung }}=8,346 ;$ Sig $=0,000$ & & \\
\hline $\mathrm{F}_{\text {tabel }}=2,39$ & $\mathrm{~N}$ \\
\hline $\mathrm{N}$ & & & \\
\hline
\end{tabular}

Sumber: data diolah, 2016 


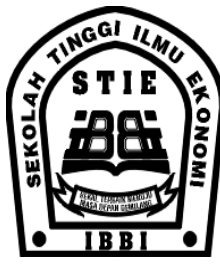

Berdasarkan data di atas maka disimpulkan hasil sebagai berikut:

Uji t digunakan untuk mengetahui apakah variabel independen secara parsial berpengaruh signifikan terhadap variabel dependen. Jika nilai $t_{\text {hitung }}$ lebih besar daripada $\mathrm{t}_{\text {tabel }}$ dan nilai signifikansi lebih kecil taraf signifikansi $5 \%$ maka variabelindependen berpengaruh secara parsial terhadap variabel dependen. Berikut penjelasan dari masingmasing hipotesis :

\section{a. Ukuran perusahaan berpengaruh negatif terhadap audit delay}

Berdasarkan tabel 4.12, diperoleh nilai koefisien regresi variabel ukuran perusahaan memiliki arah negatif sebesar $-8,890$ dan $t_{\text {hitung }}$ sebesar $-5,712$ dengan nilai signifikansi sebesar 0,000. Hal ini menunjukkan bahwa nilai signifikansi lebih kecil dari taraf signifikansi $5 \%(0,000<0,05)$ dan $t_{\text {hitung }}$ lebih besar dari $t_{\text {tabel }}(5,712>1,673)$, maka hipotesis diterima. Ini berarti bahwa ukuran perusahaan mempunyai pengaruh negatif terhadap audit delay perusahaan LQ45 yang terdaftar di BEI tahun 2013-2014. Arah koefisien yang negatif menunjukkan bahwa semakin besar ukuran perusahaan (total aset) maka audit delayakan semakin singkat.

\section{b. Umur perusahaan berpengaruh negatif terhadap audit delay}

Berdasarkan tabel 4.12, diperoleh nilai koefisien regresi variabel umur perusahaan memiliki arah negatif sebesar $-0,056$ dan $t_{\text {hitung }}$ sebesar -0,726 dengan nilai signifikansi sebesar 0,471. Hal ini menunjukkan bahwa nilai signifikansi lebih besar dari taraf signifikansi $5 \%(0,471>0,05)$ dan $t_{\text {hitung }}$ lebih kecil dari $t_{\text {tabel }}(0,726<1,673)$, maka hipotesis ditolak. Ini berarti bahwa umur perusahaan tidak memiliki pengaruh yang signifikan terhadap audit delay perusahaan LQ45 yang terdaftar di BEI tahun 2013-2014.

\section{c. Kompleksitas operasi perusahaan berpengaruh positif terhadap auditdelay}

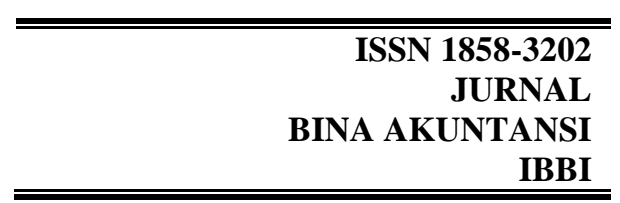

Berdasarkan tabel 4.12, diperoleh nilai koefisien regresi variabel ukuran perusahaan memiliki arah positif sebesar 0,114 dan $t_{\text {hitung }}$ sebesar 2,748 dengan nilai signifikansi sebesar 0,008 . Hal ini menunjukkan bahwa nilai signifikansi lebih kecil dari taraf signifikansi $5 \%(0,008<0,05)$ dan $t_{\text {hitung }}$ lebih besar dari $\mathrm{t}_{\text {tabel }}(2,748>1,673)$, maka hipotesis diterima. Ini berarti bahwa ukuran perusahaan mempunyai pengaruh positif terhadap audit delay perusahaan LQ45 yang terdaftar di BEI tahun 2013-2014. Arah koefisien yang positif menunjukkan bahwa semakin besar kompleksitas operasi perusahaan maka audit delayakan semakin lama.

\section{d. Reputasi KAP berpengaruh negatif terhadap audit delay}

Berdasarkan tabel 4.12, diperoleh nilai koefisien regresi variabel ukuran perusahaan memiliki arah positif sebesar 18,039 dan $\mathrm{t}_{\text {hitung }}$ sebesar 2,595 dengan nilai signifikansi sebesar 0,012. Hal ini menunjukkan bahwa nilai signifikansi lebih kecil dari taraf signifikansi $5 \%(0,012<0,05)$ dan $t_{\text {hitung }}$ lebih besar dari $\mathrm{t}_{\text {tabel }}(2,595>1,673)$, maka hipotesis diterima.

Pengujian hipotesis ini dimaksudkan untuk megetahui apakah terdapat pengaruh negatif antara reputasi KAP dengan audit delay, meskipun hipotesis diterima, namun arah pengaruhnya berlawanan dengan hipotesis yang dibuat. Sehingga dapat disimpulkan bahwa reputasi KAP mempunyai pengaruh positif terhadap audit delay perusahaan LQ45 yang terdaftar di BEI tahun 2013-2014.Arah koefisien yang positif menunjukkan bahwa perusahaan yang menggunakan jasa KAP Big Fourjustru akan memperpanjang audit delay.

\section{e. Opini audit berpengaruh negatif terhadap audit delay}

Berdasarkan tabel 4.12, diperoleh nilai koefisien regresi variabel umur perusahaan memiliki arah negatif sebesar $-6,841$ dan $t_{\text {hitung }}$ sebesar -1,616 dengan nilai signifikansi sebesar 0,112. Hal ini menunjukkan bahwa nilai signifikansi lebih besar dari taraf signifikansi $5 \%(0,112>0,05)$ dan $\mathfrak{t}_{\text {hitung }}$ lebih 


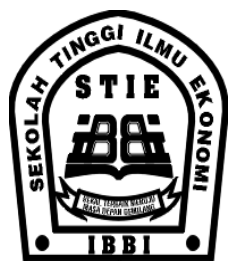

kecil dari $t_{\text {tabel }}(1,616<1,673)$, maka hipotesis ditolak. Ini berarti bahwa opini audit tidak memiliki pengaruh yang signifikan terhadap audit delay perusahaan LQ45 yang terdaftar di BEI tahun 2013-2014.

\section{KESIMPULAN}

Berdasarkan hasil pengujian empiris menggunakan regresi berganda maka didapat kesimpulan bahwa:

Variabel yang mempengaruhi audit delay adalah

UkuranPerusahaan, KompleksitasOperasi, Reputasi KAP, sedangkan variabel yang tidak mempengaruhi audit delay adalah Umur Perusahaan dan Opini Audit

\section{Daftar Pustaka}

Angruningrum, S., \& Wirakusuma, M. G. 2013.Pengaruh profitabilitas, leverage, komite audit pada audit delay. E-Jurnal Akuntansi (5.2), Hal. 251-270.

Apriliane, M. D. 2015. Analisis fakttor-faktor yang mempengaruhi audit delay (studi empiris pada perusahaan pertambangan yang terdaftar di bursa efek indonesia tahun 2008-2013).Skripsi.

IAI. 2001. Standar Profesional Akuntan Publik. Jakarta. Salemba Empat.

Indra, N. S., \& Arisudhana, D. 2013.Faktorfaktor yang mempengaruhi audit delay pada perusahaan go public di indonesia (studi empiris pada perusahaan property dan real estate di bursa efek di bursa efek indonesia.

Jama'an. 2008. Pengaruh mekanisme corporate governance, dan kualitas kantor akuntan publik terhadap integritas informasi laporan keuangan (studi kasus perusahaan publik yang listing di bej. Accounting Journal.
ISSN 1858-3202

JURNAL

BINA AKUNTANSI

IBBI

Kartika, A. 2009.Faktor-faktor yang mempengaruhi audit delay di indonesia (studi empiris pada perusahaanperusahaan lq 45 yang terdaftar di bursa efek jakarta). Jurnal Bisnis dan Ekonomi (JBE), Vol. 16 (1), Hal.1-17.

2011. Faktor-faktor yang mempengaruhi audit delay pada perusahaan manufaktur yang terdaftar di bei. Dinamika Keuangan dan Perbankan, Vol. 3, Hal.152-171.

Kusumawardani, F. 2013. Faktor-faktor yang mempengaruhi audit delay pada perusahaan manufaktur. Accounting Analysis Journal.

Latifa, F. L. 2015. Pengaruh profitabilitas, leverage, kompleksitas operasi, reputasi kap dan komite audit. Surakarta. Universitas Muhammadiyah Surakarta.

Melani, A. 2014, 30 Juni.Telat beri laporan keuangan, otoritas bursa suspensi 5 saham.

http://www.liputan6.com/bisnis/read/20 70658/telat-beri-laporan-keuanganotoritas-bursa-suspensi-5-saham(diakses 9 Februari 2016).

Nomor:Kep-11/PM/1997, K. K. (n.d.). Pedoman Mengenai Bentuk dan Isi SPernyataan Pendaftaran Dalam Rangka Penawaran Umum Oleh Perusahaan Menengah Atau Kecil. Peraturan IX.C.7. Jakarta. www.bapepam.go.id.

Nomor:Kep-431/BL/2012, K. K. (n.d.). Penyampaian Laporan Emiten atau Perusahaan Publik. Peraturan X.K.6. Jakarta. www.bapepam.go.id.

Petrolina, T. A. 2007. Analisis skala perusahaan, opini audit, dan umur perusahaan atas audit delay. Jurnal Akuntabilitas, Vol. 6 (2), Hal.129-141. 


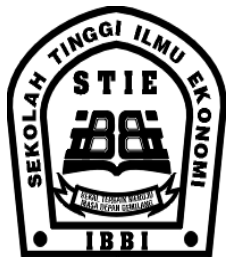

Puspitasari, E., \& Sari, A. N. 2012.Pengaruh karakteristik perusahaan terhadap lamanya waktu penyelesaian audit (audit delay) pada perusahaan manufaktur yang terdaftar di bursa efek indonesia. Jurnal Akuntansi \& Auditing, Vol. 9 (1), Hal.1-96.

Rahayu, S. K., \& Suhayati, E. 2010.Auditing Konsep Dasar dan Pedoman Pemeriksaan Akuntan Publik.Edisi 1.Yogyakarta. Graha Ilmu.

Sa'adah, S. 2013. Pengaruh ukuran perusahaan dan sistem pengendalian internal terhadap audit delay (studi empiris pada perusahaan manufaktur yang terdaftar di bei). Padang. Universitas Negeri Padang.

Saleh, R. 2004. Studi empiris ketepatan waktu pelaporan keuangan perusahaan manufaktur di bursa efek jakarta. Tesis.

Subekti, I., \& Widiyanti, N. W. 2004.Faktorfaktor yang berpengaruh terhadap audit delay di indonesia. Simposium Nasional Akuntansi VII , Hal. 991-1002.

Sugiyono. 2005. Metode Penelitian Bisnis, Edisi kedelapan, Alfabeta, Bandung.

Umar, Husein. 2013. Metode Penelitian untuk Skripsi dan Tesis Bisnis, Edisi kedua, Rajawali Pers, Jakarta.

Wolk, H., M.G.Tearny, \& J.L.Dodd. 2001. Accounting Theory : A Conceptual and Institutional Approach. Fifth Editon.Ohio : South-Western College Publishing.

www.idx.co.id (diakses 15 Februari 2016)

Yulianti, A. 2011.Faktor-faktor yang berpegaruh terhadap audit delay: studi empiris di bej. Skripsi Akuntansi. 